\title{
Labour Force Participation of Cameroonians in Informal Sector
}

\author{
${ }^{1}$ Tchakounté Njoda Mathurin, ${ }^{2}$ MBAM Ulrich Gaetan \\ ${ }^{1}$ Lecturer, FSEG, University of Ngaoundéré, Ngaoundéré, Cameroon \\ ${ }^{2} \mathrm{PhD}$ candidate, FSEG, University of Yaoundé, Yaoundé, Cameroon
}

\begin{abstract}
In this paper, we analyse the Labour Force Participation Rate (LFPR) of informal workers in Cameroon. We also estimate the effects of some determining factors on LFP decisions. We use data from the Cameroon National Institute of Statistics (CNIS), a three-wave panel obtained respectively in 2001, 2005 and 2010 for a sample of individuals in the labour market. The sample data of the national population is representative. All information's on demographic, socioeconomic and employment characteristics used in this study are provided by the CNIS database. It is particularly remarkable that the LFPR in informal sector increased substantially during latest years, particularly those of young workers. This rise in the LFPR is principally explained by the significant increase in the labour-market activity of the urban younger generation which has been improved by migration. Estimating a simple model of LFP with logistic methodology, we find that poverty, age and urbanization are significantly related with LFPR of informal labour market in Cameroon.
\end{abstract}

Keywords: Informal employment, LFPR, Poverty, Age, Urbanization

\section{INTRODUCTION}

The rate of labour market activity is one of the indicators that determine the labour market dynamics. Its fluctuation indicates the labour market capacity of job creation. The Labour Force ${ }^{1}$ Participation Rate (LFPR) has sensibly increased in Cameroon labour market (Tingum, 2016). For example, the employment rate was 66.4 percent in 2010 against 68.3 percent in 2005 . In addition, the rate of activity which has reached 77.1 percent has decreased by more than 2 points as compared to its 2005 level for the working population aged between 15 and 64 years. Between these ages, the participation rate culminated in 79.1 percent. At first glance, these data seem to reflect a full-employment situation across all types of activity. The closer analysis makes it necessary to qualify these results and point out that these participation levels designate more the extent to which people are occupied, rather than levels of access to real jobs regarding years and length of work.

Despite the decrease in the rate of activity, the salary rate at the national level was 20.2 percent in 2010 against 18.0 percent in 2005, and the employment supply was largely dominated by the informal sector which accounted for 90.0 percent in 2015 and 90.4 percent in 2010 (SEIS, 2010; UNDP-CMR, 2013; and Nana et al., 2015). Thus, it appears that non-standard employment represents a major form of labour market activity for a large number of working Cameroonians. The principal results of the surveys carried out in 2010 and 2015 on employment and the informal sector show that around seven people out of 10 are economically active people (69 percent in

\footnotetext{
${ }^{1}$ To calculate the labor force, one should sum the regular employment, open unemployment, and the number of participants in labor market. The participation rate is therefore the total number of persons in the labor force - divided by the number of persons in the working-age population.
} 


\section{Tchakounté Njoda Mathurin, MBAM Ulrich Gaetan \\ Labour Force Participation of Cameroonians in Informal Sector}

2010, and 70 in 2014). The LFPR amounts to 74.1 percent in men and 64.2 percent in women. In the urban area, 67.2 percent of men are economically active as against 52.2 percent of women. On the other hand, in rural areas, the difference between the activity rate of men and that of women is less pronounced. There is little difference between the rates for men and women owing to the high number of women working in rural areas ${ }^{2}$. As a matter of fact, nearly eight men out of ten are active against seven out of ten women with the difference of 6.4 points.

Like many others, most Sub-Saharan African Regions are characterized by dualism, large and growing regional inequalities in access to formal (non - agricultural) employment (Njikam, Lontchi, and Mwaffo, 2005; Komon and Tchakounté, 2008). Cameroonian informal sector has expanded dramatically over the past decades, especially, in urban areas. It is acquiring a predominant role, especially, in satisfying domestic demand and bringing young people and women.

It is particularly important, given the question on measuring informality, to carefully distinguish between informal and formal employment sector. Since Keith Hart first proposed the expression "informal sector" in the early 1970's to illustrate the range of subsistence activities of the urban poor, there has been considerable debate about what exactly the term refers to. The most accepted definition is from the International Labour Organisation's (ILO) (1972) which defines informal activities as "a way of doing things", characterised by: "ease of entry; reliance on indigenous resources; family ownership of enterprises; small scale of operation; labour intensive and adapted technology; skill acquired outside of the formal school system and unregulated and competitive markets".

With respect to the labour market, Eapen (2001) shows how some analysts define informality in terms of the non-existence of characteristics that concern "formal" activities like security/regularity of work, better earnings, existence of non-wage and long-term benefits, protective legislation and union protection. The ILO (2002) and the $17^{\text {th }}$ International Conference for Labour Statistics (ICLS) have proposed an alternative description using the employment characteristics of the worker. According to this explanation - presented at the 2002 ICLS - the informal economy comprises of informal employment (without secure contracts, worker benefits or social protection) of two forms:

- $\quad$ The informal employment in informal enterprises (for small unregistered or unincorporated enterprises) includes employers, employees, account operators and unpaid family workers in informal enterprises.

- The informal employment outside informal enterprises (for formal enterprises, for households or with no fixed employer), includes domestic workers, casual or day labourers, temporary or part-time workers, out-the-industry workers (including home-based workers) and unregistered or undeclared workers.

Sometimes known as undeclared, hidden or grey employment, informal employment can be broadly described as employment engaged in producing legal goods and services where one or more of the legal requirements associated with employment do not comply with OECD (2008). The informal economy itself is traditionally viewed as the deprived or disadvantaged sector employing unskilled, less educated, and urban migrants (Mazumdar, 1983). Thus, it plays a negative role in the economy by decreasing official output, reducing government tax revenue and constraining the growth of the private sector (Johnson et al., 1997; Lacko, 2000). Furthermore, the informal employees lack social security coverage and some or all of the protections provided by labour contracts.

Even though the expression has been very widely used, its meaning is not shared by all analysts. There is no precise definition and consensus over what constitutes informal sector employment and

\footnotetext{
2 The two main groups outside the active population are "young people in education and women homemakers. Seven non-working people out of ten have chosen this status because they consider that they are not of working age or do not need to work in order to earn a living" (CNIS, 2005).
} 


\section{Tchakounté Njoda Mathurin, MBAM Ulrich Gaetan \\ Labour Force Participation of Cameroonians in Informal Sector}

how to abstract it. In many cases, researcher's choice of definition is determined by the accessibility of statistic information. Thus, in many cases, the informal sector has been referred to as street vendors, domestic workers or unregistered small-scale activities in developing countries, and drug trafficking and prostitution in western countries. Some authors declare that all selfemployed workers should be incorporated in the informal sector, while others consider only those who are not paying social security contributions and are outside any employment protection. Legalistic definition of informality refers to the avoidance of formal registration, taxation and the lack of social security protection.

Merrick (1976) defines informal sector workers by their lack of social security status. Pradhan and van Soest (1995) use a definition of fewer than six employees for Bolivia and Mexico, but Funkhouser (1997) undervalues fewer than five employees for an analysis of five Central American countries. The ILO (2003) definition is based on employees in small establishment, size of fewer than 5-10 employees (depending on the country). Under the guidelines of the statistical definition of informal employment established by the ICLS in 2003, informal employment covers casual jobs or jobs with limited short duration; jobs with hours of work or wages below a specified threshold; employment of persons in households; jobs where the employee's place of work is outside the premises of the employer's enterprise; or jobs for which labour regulations are not applied (Daza, 2005). Finally, Henley et al. (2009) indicate three definitions of informality: first, to the employment contract status; second, to the social security protection, and third to the nature of the employment and the characteristics of the employer. More specifically, the way of defining informality in developing countries does matters and the conditional outcome of particular factors on the likelihood of informality varies greatly from one definition to another. Where information on contract status is not available, the alternative definition of informal employment is the lack of social protection. For instance, Portes et al. (1989), Marcouiller et al. (1997) and Maloney (1999) classify workers as informal employees by the criterion of no social protection and security. Bernabe (2002) applies the typology of informal employment by using proxies for household enterprises and non-regular employment. A study by Gasparini and Tornarolli (2009) defines as informal employees who are engaged in low-productive jobs, often family-based activities. There are a group of researchers who view the informal labour market in line with the survival-oriented informal activities (Johnson et al., 1997; Abdulloev et al., 2012).

The Cameroonian literature on informal employment is moving away from a traditional view of informality as evidence for labour market segmentation (Tchakounté, 2008; Ningaye and Talla Fokam, 2014). Rather than seeing informal employment as a survival mechanism for lowproductivity workers who are queuing until they find a better-paid job opportunity, new empirical studies argue that some informal workers "choose" informal employment. They do so since informal employment offers them a better financial return on their skills or experience (OECD, 2008). Additionally, informal sector gives flexibility in hours, place of work, and allows small businesses with entrepreneur ability to become successful. Maloney (1999) suggests that the informal sector in developing countries may be a desirable choice. Individuals working in the informal sector benefit from flexibility regarding working hours and in some cases the choice of work location. Women with children may especially value this aspect. At the same time, because wages of the "unofficially employed" are not subject to taxation, salaries in the informal sector may be significantly higher compared to post-tax salaries in the formal sector. This view suggests that workers may face an improved wage present in the informal sector compared to the formal sector (Henley et al., 2009).

An issue that arises is whether the different definitions formulated above would be more appropriate to capture the informal economy in Cameroon. In the following lines, we adopt the definition of Cameroon National Institute of Statistics (CNIS) (2005) which is simple and more correct in point of view of statistical information used in our empirical approach: "the informal 


\section{Tchakounté Njoda Mathurin, MBAM Ulrich Gaetan \\ Labour Force Participation of Cameroonians in Informal Sector}

sector/employment in Cameroon means one person businesses without a tax identification number and/or without any formal accounting system"3.

As noted above, Cameroon certainly shares with the other developing countries a lot of common features in informal patterns. As such, there is no motivation to believe that standard economic models of LFP that have been utilized in studying the cases of developed countries cannot be applied to Cameroon. Hence, our study found that the LFPR of young male and female in informal sector increased substantially during the last decades, largely explained by the remarkable increase in the labour-market activity of the urban younger population. According to SEIS (2010), most of the employments held by young people aged between 15-34 years in 2009 are concentrated in the informal sector (57.8 percent). The World Bank (2015) estimate that 87 percent of women in the labour force were employed in vulnerable employment compared to 67 percent of men, and 58 percent of women in the labour force were employed in (informal) agriculture compared to 49 percent of men. Our paper suggests that the acceleration of population non-aging in urban areas due to the selective out-migration of younger persons was the major cause of the sharp increase in the LFPR of young males and females.

An improved understanding of the contribution of a different factor on LFP on informal employment is crucial for addressing country's general labour market and consequences. In this regard, the present study complements the existing literature by capturing the diversity of informal employment in Cameroon and estimating a model of LFP along several dimensions.

The remainder of the paper is structured as followed. In section 2, we provide some major characteristics of the Cameroonian's labour market. A simple model of LFP is built in Section 3, illustrating a brief description of data. In section 4, we discuss the main econometric results. Finally, section 5 concludes.

\section{MAJOR CHARACTERISTICS OF THE INFORMAL LABOUR FORCE}

According to the CNIS (2011), the structure of Cameroonian labour market clearly shows a domination of the primary sector (agriculture, breeding which continues to employ the majority of Cameroonians (56 percent), compares to service and trade (32 percent) or manufacturing (14 percent). The overall labour market trends have shown a constant decline in the number of public sector jobs and an urbanization of employment since the beginning of the 1980 s.

The government turned to international donors, to stop the progress of the recession of the early 1990s, which imposed a Structural Adjustment Program (SAP). By aiming to make large cuts in public spending, these SAP policies phased out ongoing investment projects brought about major civil service staff reductions and encouraged a shift towards privatization. On the whole, the SAP had a major impact on employment, forcing the country to move from a position where the State was the main provider of employment, to one where the private sector had to take on this responsibility with the supply of more competitive jobs. According to a report by the ILO's Employment Strategy Department in Geneva (Njikam, Lontchi, and Mwaffo, 2005), downsizing of the civil servant led to 60,000 administration employees being made redundant between 1989 and 1997 , as well as to a drastic fall in the number of salaried employees, from 63.9 percent to 22.1 percent between 1983 and 1993 in industry, and from 20.6 percent to 12.6 percent in the trade sector.

Cameroon like many other developing countries has experienced rapid urbanization in the last two decades. While the natural growth of population has been the major contributor to this urbanization, migration from rural areas to urban centers has been the most important factor (Tchakounté and Feubi Papem, 2016). Rapid urbanization in Cameroon is associated with some

\footnotetext{
${ }^{3}$ Within the meaning of the Organization for the Harmonization of Business Law in Africa chart of accounts.
} 
development challenges. Key among these challenges is the deterioration in urban physical environments and the general living conditions (EDSC-III, 2004).

Poverty in Cameroon is largely a rural phenomenon however the proportion of the poor who live in urban areas is increasing fast. In 2001, the proportion of urban poor was estimated at 12.2 percent compared to 52.1 percent in rural areas. In 2007, the figure had risen to 17.9 percent compared to 55 percent in rural areas. Substantial urban poverty not only limits the scope for mobilising the revenue of urban authorities but more importantly also it limits the effective demand for housing and other basic urban services due to low income.

If the LFPR is 71.5 percent for people aged 10 and over, this rate can illustrate the worrying phenomenon of child labour. The statistics indicate that 39.9 percent of children aged between 10 and 17 have been identified as being employed (i.e. 1.41 million children are engaged in employment), particularly in rural areas where over one in two children work (as opposed to 12.3 percent in urban areas). Child labour remains a concern in Cameroon.

Whereas participation rates for persons aged 15 to 64 have been on the increase, there is a relatively low unemployment rate in the ILO sense of the term, given that it is evaluated at 4.2 percent for men and 4.6 percent for women. This expands to 5.2 percent and 7.3 percent respectively if the wider notion of unemployment is used, in other words, if it includes "people who have not worked, even for one hour, in the seven days preceding the survey and who are seeking employment and prepared to start work immediately", as well as "people who have not sought employment during the reference period, but would nonetheless be available if asked" (Njikam, Lontchi, and Mwaffo, 2005).

The Cameroonian unemployment rate is inversely proportional to the number of years of education completed in school. It is 3.1 percent for those who have reached the end of primary education, 10.7 percent for those leaving secondary education and 13.4 percent for those who have been to university. CNIS (2011) survey also mentions discouraged job seekers, a category that accounts for 4.9 percent of people not working in Cameroon and who have "a level of education higher than other jobless, with an average of nearly three extra years of study." All these statistics clearly show that employment structure is heavily weighted towards low levels of qualification.

Moreover, observable underemployment, which describes individuals working involuntarily for less than 35 hours per week in the CNIS (2011) survey results, affects 12.1 percent of the economically active population, primarily in urban areas. On the other hand, invisible underemployment, which concerns "workers whose wages are lower than the guaranteed hourly minimum" CFAF 36270 per month for 40 hours' work, which is about $€ 55.3$, accounts for about 69.3 percent of the economically active population, with a proportion of 78.6 percent in rural areas and 45.7 percent in urban areas. In general, underemployment affects 75.8 percent of the economically active population, with the proportion being 16.7 percent of civil servant employed in the public sector and 23.7 percent for agents employed in the formal private sector. It is less prevalent among skilled workers than among unschooled people and is seriously present among persons working in the informal sector ${ }^{4}$. The size of underemployment is pressing Cameroonians to develop strategies or prospect to increase their income. Thus multiple job holding rates reach up to 37 percent and are particularly high in rural areas, where underemployment affects 83.6 percent of workers as opposed to 68.3 percent in urban areas.

The predominant position of the informal sector is highlighted when analysing the breakdown of jobs per institutional sector: we have already indicated that it employs over 90 percent of the economically active population. Thus, this labour market structure can mostly be explained by the role played by informal agricultural jobs, which alone account for 55.2 percent of total employment, whereas non-agricultural informal jobs account for 35.2 percent. The other 9.6

\footnotetext{
${ }^{4} \mathrm{~A}$ percentage of 86.8 percent of people working in the informal agricultural sector and 70.6 people working in the non-agricultural informal sector are affected by this situation.
} 


\section{Tchakounté Njoda Mathurin, MBAM Ulrich Gaetan \\ Labour Force Participation of Cameroonians in Informal Sector}

percent of jobs, offers by the formal sector, are equally divided between the public and private sectors.

Another observation of the real situation in the non-agricultural informal sector reveals the importance of micro-businesses ${ }^{5}$ and self-employment. These two categories of informality together represent nearly 90 percent of informal jobs, and they each account for about half this total. The detailed information shows that services sector accounts for 66 percent of these jobs, and the proportion is 28 percent for trade. Furthermore, 21.3 percent work in real professional premises, and 23 percent are street vendors and market traders.

As far as average incomes are concerned, non-agricultural informal employees earn an hourly wage that is three times lower than formal sector workers, and informal employees in the agricultural sector earn eleven times less. The working conditions of the non-agricultural informal sector workers reveal some others negative aspects. There is a 3.2 percent likelihood of their having a pay slip and a 10.8 percent likelihood of their having an employment contract of fixed or open duration. This proportion falls to 0.7 percent and 2.6 percent for those working in the informal agricultural sector. Decent working conditions are therefore largely inaccessible goal for such workers whose LFP constitute the majority.

\section{MODEL OF LABOUR FORCE PARTICIPATION DECISIONS}

This section presents a simple economic model, the different variables, and the datasets use to analyze the informal labour market participation.

\section{A simple standard model}

The theoretical model we developed is a version of nonlinear model of Labour Force Participation (LFP) decisions based on a choice between work and leisure (Pencavel, 1986; Blundell and McCurdy, 1999). The model is formulated in such a way that at any given date, a worker will choose either leisure or informal LFP based on his or her utility associated with each alternative. To make a choice to participate or not in the labour market, any person is supposed to attach some level of utility $U$, to any possible option choice.

Let $U_{w}$ denotes the well-being utility, $Y$ the labour income, $N$ the non-labour income, $Z$ a vector of demographic and socioeconomic variables to affect utility, and $\bar{H}$ the hours of work in the labour market. Therefore, the individual's utility function when working is:

$$
U_{w}(Y+N, \bar{H} ; Z) \text {, }
$$

moreover, utility function when not working can be written as

$U_{R}(N, 0 ; Z)$,

Suppose that utility is a concave increasing function of each argument, the entire decision function in the two cases can be expressed as a combination of preceding relation (1) and (2)

$I^{*}=U_{R}(N, 0 ; Z)-U_{w}(Y+N, \bar{H} ; Z)$, (3)

where $I^{*}$ is a critical or threshold level of the index.

$I^{*}$ is not observed, but his value is related to an observed indicator, $I$. Suppose that the amount 1 represents the leisure and 0 the LFP, the discrete leisure $I=0$, if $I^{*}<0,=1$ otherwise.

If we define $X$ as a vector containing proxy variables for $Y, N, \bar{H}, \mathrm{~A}$ a matrix of poverty dummies, $C$ a matrix of cohort dummies, $Y$ a matrix of year dummies, $Y, a, \beta$, and $\phi$ are parameter vectors, and $\varepsilon$ an error term, the LFP decision function, based on the maximization of the worker's utility, can be written as

$I^{*}=U_{R}(N, 0 ; Z)-U_{w}(Y+N, \bar{H} ; Z)=-X^{\prime} \beta-A \alpha-C \gamma-Y \varphi+\varepsilon$.

Assuming that the indicator function $I^{*}$ is not normally distributed with the same mean and variance like $I$, permit us to not only to estimate (by means of a logit model) the parameters of the

${ }^{5}$ Called microenterprises, because they employed less than six workers 
index but also to get some information about the unobservable index itself. Relations (5) give the logit model used to estimated the effects of the variables

$\operatorname{Prob}(I=1)=\operatorname{Prob}\left(\varepsilon<X^{\prime} \beta+A \alpha+C \gamma+Y \varphi\right)$

$=\frac{\exp \left(X^{\prime} \beta+A \alpha+C \gamma+Y \varphi\right)}{1+\exp \left(X^{\prime} \beta+A \alpha+C \gamma+Y \varphi\right)}$

$=\Phi\left(X^{\prime} \beta+A \alpha+C \gamma+Y \varphi\right)$.

The logit model is used here to find out in a more general sense what factors explain workers' decision to participate in the informal labour market. The presence of linear relationship across the three matrices $A, C$, and $Y$ modifies the expression of dummies matrices $A$ like

$A s_{a}=C s_{c}+Y s_{y}$

where the vectors $s$ are simple arithmetic sequences $\{0,1,2,3, \ldots\}$ of the length given by the number of columns of the matrix that pre-multiplies them. The form given in equation (6) is a single identity. Since the endogenous variable is also an identity, it is impossible to estimate the equation (5). The problem can be circumventing by: (i) drop cohort dummies from the regression equation, and ignoring the cohort effect. (ii) Normalizing the poverty, cohort, and year effects. In this second procedure, we suppose that any secular time trend in the LFPR of a person is attributable to the poverty and cohort effects and that the year effect captures the cyclical fluctuations or business cycle effect. The particular normalization mechanism that accomplishes this makes the year effect orthogonal to a time-trend, in such a way that,

$s_{y}^{\prime} \varphi=0 .(7)$

It is now possible to estimate system (5) subject to the normalization given by equation (7), by defining three-year dummies defined as follows, from $t=3,4,5$ and including them the regressions. Let $d_{t}$ be the usual year dummy, it follows that the remains $d_{t}^{*}$ can be given as

$d_{t}^{*}=d_{t}-\left[(t-1) d_{2}-(t-2) d_{1}\right]$.

The process (8) satisfies the restriction that the year dummies should add to zero, as well as the restriction (7). The factors coupled to $d_{i}^{* \prime} s$ provide the third to the final year (2005 through 2010 in the present case) parameters. It is possible to compute the first and second from the two restrictions that all year effects add to zero thus, satisfying relation (7).

To provide an empirical presentation of the situation of LFP in the labour market of Cameroonian informal sector, it is necessary to decompose the set of explanatory variables. These explanatory variables include among important position for our study: poverty, age, educational attainment, duration status, characteristics of prior occupation, and family structure ${ }^{6}$. The first, four variables (poverty, age, education, and duration status) are a proxy for the individual's productivity in the informal labour market, which determines the opportunity cost of leisure. We believe that the preference for work is associated with duration, and the remains variables (family structure, and job attributes such as flexibility and physical demands). Nothing that the selection of explanatory variables used in this study was limited by the information available from the CNIS dataset, though it would be desirable to consider all the potential determining factors of LFP of informal workers. For all that, to achieve consistency between the theoretical framework and current variables, we propose an estimation strategy that introduces a systematic way to embed non-linearities into the standard empirical specification.

Three major observations should be noted concerning the incidence of variables in the model. First, in most important, we utilize independent variables poverty, urbanization, and age as a dummy variable for each of the five-year age intervals. Poverty had become a central goal for development with halving extreme poverty by 2015 constituting the first, and perhaps the most critical goal among the Millennium Development Goals. The concept of "poverty line" is used to indicate the minimum level. CNIS surveys have emphasised the importance of income poverty, which is measured by a consumption-based poverty line that can be defined as the amount of expenditure

\footnotetext{
${ }^{6}$ For a complete list, see:

http://ec.europa.eu/eurostat/statistics-explained/index.php/EU_statistics_on_income_and_living_conditions_\%28EU-SILC\%29__variables
} 


\section{Tchakounté Njoda Mathurin, MBAM Ulrich Gaetan \\ Labour Force Participation of Cameroonians in Informal Sector}

required for acquisition of minimum food. Concerning urbanization, a dummy variable of the urban zone is included to measure the difference between urban and rural areas. The current urban population growth of about 5 percent per year in the main Cameroonian cities (Yaoundé, Douala, Bafoussam, Garoua) is particularly attributed to the rural exodus which accounts for a rate of about 2.8 percent per year (Jaza Folefack, 2015). The rural migration primarily affected the young people aged between 15 to 35 years. This age group accounts for 30.3 percent of the total population of Cameroon, but over 36 percent of these young individuals are strongly hit by poverty?. The age variable is globally ranging from 15 to 65 years. If age is included as a continuous variable, the results do not show much change. Age has a strong negative effect on the odds of LFP (see section 4), and the parameter estimates of other explanatory variables remain practically unchanged.

Second, Educational attainment in the analysis is also represented by the dummy variables denoted as "No schooling," "Elementary school," "Middle school," "High school," and "College." It is well known that the degree of education is positively correlated with the size of the labour supply (Pencavel, 1986). However, the concentration of Cameroonian workforce of the low level of education appears as an obstacle to obtaining decent jobs. Beyond doubt, accumulation of human capital in the form of education will increase wages, raising the opportunity cost of retirement which represented the so-called substitution effect. However, because no income measure is included in the present analysis, the variables of education could also capture the effect of income. Therefore, we conclude that the direction of the effect of education will depend on the relative magnitudes of the substitution and income effects.

Third, so as to capture the potential effects of having dependents and receiving family support, two others variables relevant to the marital status and the family size are integrated. It is possible that a larger family will require a greater household income, but will also have a greater potential for earnings from more family members. For that reason, the sign of the impact of the number of potential earners will depend on the relative sizes of these two different influences.

The dichotomous nature of regression model, as well as the definition of different variables considered in this paper, is subject to limitations arising above all from the cross-sectional nature of the data, to which one can add the lack of information on a number of key determinants of the labour force participation decisions, including (i) The proxy variables placed in this study, such as age and education, are highly incomplete measures of labour and non-labour incomes. (iii) To boot, it well knows that some of the independent variables may have endogeneity problems. For instance, the family size could reflect outcomes rather than determine the factors of leisure decisions. (iii) The leisure effect of job attributes cannot be considered fully in the model because information on the previous occupation and industry is unknown for the leisure. Although our theoretical analysis focused exclusively on determined characteristics of individuals participating in informal labour activities, the predictions are likely to have been more or less the same had we used a more complex model that also allowed for complete interactions.

\section{Data}

The data used for the empirical investigation of this paper come totally from 2001, 2005 and 2010 informal labour surveys conduct in Cameroon. The recent nationally-representative survey has a valid case of 18,257 individuals and households and primary include data on demographics and employment characteristics of household members and head of household. The main variables used in the analysis are: areas, age, gender, type of occupation (formal/informal), hours worked, employment status (public/private, economic activity), marital status, education attainment, and poverty data information. Our analysis also uses data from the 2010 informal employment survey of 27,000 individuals. The survey does not contain data on wages (except details on concerning qualitative information on wage), but it does provide other detailed information about informality

\footnotetext{
${ }^{7}$ According to Emini et al. (2005), poverty is the major factor encouraging their movement from the village to the city leaving, thereby, only the older people in the village.
} 


\section{Tchakounté Njoda Mathurin, MBAM Ulrich Gaetan \\ Labour Force Participation of Cameroonians in Informal Sector}

(duration, preferences of working). It also includes detailed information quantitative and qualitative aspects of informal employment that allows researcher to study some of these characteristics. Table A1 of the Appendix contains a description of the dependent and independent variables including the means and standard deviations. To examine the existence of multicollinearity among the independent variables, we get aid from the correlation matrix. The pairwise correlation among different explanatory variables is reported in Table A2. Because all correlations are less than $\mathbf{0 . 8 3}$, there is no sign of high multicollinearity among variables.

A variety empirical methods should be used to address problematic we identified. First, descriptive statistics are used to describe the structure of labour force ${ }^{8}$ in Cameroon. Second, logistic regressions are used to analyze the correlates of LFP and individual characteristics (Tables 1-4). For these regressions, we return to ECAM and SEIS labour force surveys, because they identify informal labour information and controlling for socioeconomic, professional and demographic characteristics. Finally, further descriptive statistics are introduced to help interpret the results of regressions analysis.

Internationally, it appears that the labour force involved in informal activities is mainly composed of the poor classes, mostly urbanized, with scarce education or low levels of qualification, which come from rural areas in search of better standards of living. Such labour force is mostly made of women, young people seeking their first job, low-wage marginal employees of the formal sector looking for alternative sources of income. In our study, we seek to verify these assumptions and give their measure taking to account the age, poverty or regional elements indicate above.

While the national surveys on the labour force in Cameroon have documented its magnitude and contribution in the national economy, little is known about the factors that determine participation decisions in the informal labour force, especially given that the rate of participation has been increasing.

\section{REGRESSION ANALYSIS AND DISCUSSIONS}

This section estimates the diverse individual's characteristics of LFP in Cameroonian informal sector. There are several dimensions to the results of the analysis described above. We start with a rapid justification of our estimation strategy before turning to our estimates. As indicated before, the estimate model is a logit, and the results present variations in the probability of participating given changes in the explanatory variables. The logistic model has been used extensively in analyzing growth phenomena, such as population, and labour force. The appropriate mode of estimation is determined by the structure of error term which in our case is not normally distributed. This means that we cannot use the familiar OLS procedure to estimate the parameters, we may have to resort to the Maximum Likelihood (ML) econometric method ${ }^{9}$.

Table 1 presents our estimate results of the basic equation 5, and the following Tables give alternative mixture regressions. Three pooled-sample logistic regressions excluding the cohort dummies are provided in Table 1 . Each case is related with mean and impact effect of all independent variables describe in the previous section. In particular, the year dummy variables (expand in equation 8) would capture Cameroon's various social, economic, and institutional changes, as well as the changing patterns of public policies and social programs such as PANEJ, PIASSI or PAJER-U ${ }^{10}$, that influenced the informal LFP decisions. By allowing these variables, we can also consider the potential business cycle effect on leisure and employment. Three regressions, give by each column, are performed separately for persons who resided in rural and urban areas, as well as the complete sample of individuals at the same ages.

\footnotetext{
${ }^{8}$ For these statistics, we also take and compare data from EDS-MIC (2011) which used a more consistent sample of 10,462 household, 10,656 women and 5,280 men aged between 15 and 59. The raison is that the sample used by EDSC is higher than those used by traditional ECAM or ESII.

${ }^{9}$ For a comparatively simple discussion of maximum likelihood in the context of the Logit model, see Demarsi (1992).

10 PANEJ: The National Pact for Youths' Employment; PIAASI: The Support Project to Actors of the Informal Sector; PAJER-U: The Support Program to the Rural and Urban Youths.
} 
Tchakounté Njoda Mathurin, MBAM Ulrich Gaetan

Labour Force Participation of Cameroonians in Informal Sector

Table 1: Results of pooled-sample logistic regressions: correlates of the probability of LFP

\begin{tabular}{|c|c|c|c|c|c|c|}
\hline & \multicolumn{2}{|c|}{ Urban } & \multicolumn{2}{|c|}{ Rural } & \multicolumn{2}{|c|}{ All } \\
\hline & Mean & Effect & Mean & Effect & Mean & Effect \\
\hline Poverty & 0.437 & $-0.886 * *$ & 0.555 & $-0.879 * *$ & 0.426 & $-0.887^{*}$ \\
\hline Poverty2 & 0.331 & $-0.756 * *$ & 0.440 & $-0.752 * *$ & 0.397 & $-0.786 *$ \\
\hline Ages 15-19 & 0.137 & $-0.328 * *$ & 0.155 & $-0.455^{* *}$ & 0.109 & $-0.402 * * *$ \\
\hline Ages 20-29 & 0.223 & $0.879 * *$ & 0.247 & $0.862 * *$ & 0.198 & $0.895 * *$ \\
\hline Ages 30-39 & 0.285 & $0.476 * *$ & 0.299 & $0.533 * *$ & 0.231 & $0.586 * * *$ \\
\hline Year 2001 & 0.094 & $0.408 * *$ & 0.222 & -0.013 & 0.145 & $0.147^{* *}$ \\
\hline Year 2005 & 0.193 & $0.990 * *$ & 0.203 & $-0.071 *$ & 0.135 & $0.096 * *$ \\
\hline Year 2010 & 0.235 & $0.226 * *$ & 0.130 & $-0.086 *$ & 0.169 & $0.480 * *$ \\
\hline $\begin{array}{l}\text { Elementary } \\
\text { school }\end{array}$ & 0.288 & $0.155 * *$ & 0.412 & $-0.015^{* *}$ & 0.339 & -0.022 \\
\hline Middle school & 0.190 & $0.213 * *$ & 0.211 & $-0.136 * *$ & 0.163 & $-0.100 * *$ \\
\hline High school & 0.246 & $0.237 * *$ & 0.010 & $-0.646 * *$ & 0.190 & $-0.096 * *$ \\
\hline College & 0.181 & $0.537 * *$ & 0.510 & $-0.347 * *$ & 0.131 & $0.120 * *$ \\
\hline Marital status & 0.619 & $1.644 * *$ & 0.192 & $2.235^{* *}$ & 0.391 & $1.199 * *$ \\
\hline Family size & 3.417 & $-0.017 * *$ & 3.266 & $-0.067 * *$ & 3.497 & $-0.043 * *$ \\
\hline $\begin{array}{l}\text { Duration } \\
\text { status }\end{array}$ & 0.321 & $0.765 * *$ & 0.478 & $0.662 * *$ & 0.191 & $0.897 *$ \\
\hline Urban region & 1.000 & $\begin{array}{l}\mathrm{N} \\
\mathrm{I}\end{array}$ & 0.000 & $\begin{array}{l}\mathrm{N} \\
\mathrm{I}\end{array}$ & 0.617 & $-0.276 * *$ \\
\hline $\begin{array}{l}\text { \% Non- } \\
\text { agriculture }\end{array}$ & 23,476 & $0.013 * *$ & 20,494 & $0.013 * *$ & 25,294 & $0.013 * *$ \\
\hline$\%$ Young -30 & 10,933 & $0.054 * *$ & 15,655 & $0.044 * *$ & 17,674 & $0.045 * *$ \\
\hline Pseudo R2 & \multicolumn{2}{|c|}{0.219} & \multicolumn{2}{|c|}{0.207} & \multicolumn{2}{|c|}{0.222} \\
\hline $\begin{array}{l}\mathrm{N} \text { of } \\
\text { observations }\end{array}$ & \multicolumn{6}{|c|}{27,000} \\
\hline
\end{tabular}

Note: Mean corrected. Effect $=$ variation $\partial P / \partial X$. Significance level: $* * * p<0.01, * * p<0.05, * p<0.1$.

The first variable of interest "poverty" is negatively related to the odds of LFP, as anticipated. Two types of poverty are considerate in conformity with our data, severe poverty (revenue $<$ minimum wage) and pure poverty or poverty 2 (minimum wage $<$ revenue $<$ mean wage). In each case, the size of the estimated coefficient in Table 1 is similar in fact for all three samples and remained stable over time; for example, the estimated coefficient are respectively $-0.886,-0.879,-0.887$ in the first case. The findings are significant at the 0.05 level. If other variables included in the regressions are held constant, the results suggested by the year dummies is that the increasing trend of the LFPR would largely disappear for poor agents residing in rural areas.

In contrast, the regression results for city location are remarkably similar to the actual changes in the LFPR. This indicates that the explanatory variables incorporated in the regressions describe better the changes in the LFPR of the rural population than those of persons living in an urban agglomeration. Concerning age, we saw in section 2 that young person's start entering informal labour force around age 10 . Around 40 percent of the worker population aged between 10 and 14 is in the labour force. The coefficients in Table 1 and other show that age of agents is significant in the two models, negative for 15-19, and positive otherwise. This shows that the probability of a person being a concern by labour force increase with age (Toossi, 2002). Although age squared (i.e. a variable to capture old age) is missed in regressions, it is expected that beyond some point, the probability of being poor should increase with age.

When we associate education and labour market activity of agents, the consequence is markedly different between rural and urban areas. For example, persons with no schooling in rural areas are 


\section{Tchakounté Njoda Mathurin, MBAM Ulrich Gaetan \\ Labour Force Participation of Cameroonians in Informal Sector}

more likely to be in the labour force than the educated (Takatoshi and Rose, 2010). In urban areas, by sharp contrast, a strong positive relationship between education and the LFP is found. In the first case, the increase in LFPR is more than fully explained by the decline of the importance of formal education due to a larger fraction of the self-employed, such as farmers. An alternative explanation could see in this a possible stronger income effect related to education in rural areas.

For both the urban and rural populations, the analysis on married persons suggests an important degree to be in the labour force than single persons (Blau and Riphahn, 1998). The higher LFP of the married could have resulted from a greater need to support dependents. If a better participation of women in the labor force is a desirable goal of Cameroonian government, an elevated LFP for married could reflect a good environment for the labour market activity of the married man owing to the spouses' assistance. However, for synthetic cohort analyses (Table 2), marriage is associated with lower odds of LFPR either among either urban population or rural areas. Analyzing household data from the second Survey of Employment and the Informal Sector (SEIS) conducted in 2010, Tingum (2016) find that married females are more likely to participate in the labour market. She justified her positive and significant coefficient by the fact that married females may not be willing to stay at home to carry out household duties.

Another demographic component shows in Table 1 concern the family size. The coefficient of this variable confirms a negative relation with the probability of the LFP for both rural and urban areas, implying that the presence of potential earners in the household enabled informal householders to leave the labour force. It appears that additional family members improved the probability of LFP of individuals more strongly in cities than in rural areas. Takatoshi and Rose (2010) findings judge the difference between rural and urban areas as reflect of the relative contribution of other family members to the family economy. As long as the proportion of self-employed jobs is higher in the countryside, the sharing of household members will be much higher in the urban areas than in the village. In such a case, the observed negative effect of the family size on the endogenous variable supports the earlier conjecture that migrations of the rural population to cities should have increased the LFPR of informal workers in urban areas.

On the other hand, poor workers who are residing in urban areas are much more likely to be active in the labour force than regional-city. It should be noted that the poor employed outside agriculture in each city and percentage of the economically active population had a significant positive impact on the probability of the LFP of a worker living in the locality. As evidence from the analysis before, urbanization results from the relative decline of agriculture in Cameroon would have greatly increased the LFPR of informal workers, other things being equal (Tiffen, 2003; Bamou and Masters, 2006).

An indicator of the degree of population youth in the locality (the percentage of the population aged -30 in each city) stands out as a very powerful predictor of the LFP of youth in informal activities. The effect of the variable "\% young -30 " on the odds of LFP is positive and statistically significant for both the rural and urban populations. The magnitude of the effect, however, is lower in the rural areas than in urban than, consistent with the assumption that the young population in urban areas caused by rural-urban migration increases the LFPR of young persons in towns.

These findings point up a major tendency owing to rural-urban migrations: the losing family labour in Cameroonian rural households is the cause of the rise of the LFPR of informal workers these last decades. Over the periods under study, economic crises, age structure, urbanization, and the relative decline of agriculture are all countervailing forces that increase the informal labour-market activity in the country. In favour of educational attainments, the LFP of youth increase in cities, and a decrease in the countryside concur with the economic activity. As a matter of fact, the decrease population aging and increase in the family size in each city could have helped boost the integration of young workers into a larger metropolis. 
Particularly large in magnitude is the effect of population poverty in urban areas. At that point, an increase of one-percent in the proportion of the young people aged -30 found expressions in a 5.4 percent rise in the probability of the LFP in those areas. This change would have produced a 48 percent increase in the LFPR of young workers during the 10 years, more than seven times the actual rise in the LFPR of population aged +30 in rural areas, since the average share of the population aged -30 in urban areas increased by 8.8 percentage points between 2001 and 2010 (CNIS, 2011). In comparison with the entire sample, the rise in the young population in each locality between 2001 and 2010 are only 3.5 percentage points, more than twice the actual rise in the LFPR of all persons aged +30 , and more than enough to cause a 16 percent increase in the LFPR of young workers.

Table 2: Results of logistic regressions for synthetic cohort analyses: correlates of the probability of LFP

\begin{tabular}{|c|c|c|c|c|c|c|}
\hline & \multicolumn{2}{|c|}{ Urban } & \multicolumn{2}{|c|}{ Rural } & \multicolumn{2}{|c|}{ All } \\
\hline & Mean & Effect & Mean & Effect & Mean & Effect \\
\hline Poverty & 0.485 & $-0.596 * *$ & 0.584 & $-0.555^{* *}$ & 0.385 & $-0.596 * *$ \\
\hline Poverty 2 & 0.431 & $-0.485^{* *}$ & 0.471 & $-0.468 * *$ & 0.274 & $-0.439 * *$ \\
\hline Ages 15-19 & 0.101 & $-0.349 * *$ & 0.143 & $-0.473 * *$ & 0.112 & $-0.413^{* * *}$ \\
\hline Ages $20-29$ & 0.211 & $0.881 * *$ & 0.273 & $0.735 * *$ & 0.179 & $0.886 * *$ \\
\hline Ages 30-39 & 0.224 & $0.458 * *$ & 0.284 & $0.549 * *$ & 0.245 & $0.595 * * *$ \\
\hline Cohort 1976 & 0.126 & 0.039 & 0.179 & $0.900 * *$ & 0.146 & $0.323^{* *}$ \\
\hline Cohort 1981 & 0.195 & $0.226 *$ & 0.185 & $1.099 * *$ & 0.191 & $0.516 * *$ \\
\hline Cohort 1985 & 0.222 & $0.251 * *$ & 0.132 & $0.743 * *$ & 0.187 & $0.463^{* *}$ \\
\hline $\begin{array}{l}\text { Dummy } \\
2001\end{array}$ & -0.039 & -0.073 & -0.085 & $-0.144 * *$ & -0.057 & $-0.070^{* *}$ \\
\hline $\begin{array}{l}\text { Dummy } \\
2005\end{array}$ & 0.026 & $0.059 * *$ & -0.225 & $-0.173 * *$ & -0.070 & $0.193 * *$ \\
\hline $\begin{array}{l}\text { dummy } \\
2010\end{array}$ & 0.034 & $-0.192 * *$ & -0.285 & $-0.092 * *$ & -0.088 & $-0.165^{* *}$ \\
\hline $\begin{array}{l}\text { Elementary } \\
\text { school }\end{array}$ & 0.288 & $0.136 * *$ & 0.412 & $-0.509 * *$ & 0.339 & $-0.049 * *$ \\
\hline $\begin{array}{l}\text { Middle } \\
\text { school }\end{array}$ & 0.190 & $0.195 * *$ & 0.211 & $-0.317 * *$ & 0.163 & $-0.122 * *$ \\
\hline High school & 0.246 & $0.213^{* *}$ & 0.110 & $-0.574 * *$ & 0.190 & $-0.119 * *$ \\
\hline College & 0.181 & $0.504 * *$ & 0.105 & $-0.654 * *$ & 0.131 & $0.087^{* *}$ \\
\hline $\begin{array}{l}\text { Marital } \\
\text { status }\end{array}$ & 0.913 & $0.978^{* *}$ & 0.821 & $2.902 * *$ & 0.916 & $1.424 * *$ \\
\hline Family size & 3.417 & $-0.016^{* *}$ & 3.526 & $-0.067 * *$ & 3.497 & $-0.042 * *$ \\
\hline $\begin{array}{l}\text { Duration } \\
\text { status }\end{array}$ & 0.411 & $0.675 * *$ & 0.380 & $0.726 * *$ & 0.201 & $0.771 *$ \\
\hline Urban region & 1.000 & $\mathrm{NI}$ & 0.000 & $\mathrm{NI}$ & 0.617 & $0.281^{* *}$ \\
\hline $\begin{array}{l}\text { \% Non- } \\
\text { agriculture }\end{array}$ & 23,476 & $0.013 * *$ & 20,494 & $0.013^{* *}$ & 25,294 & $0.013 * *$ \\
\hline$\%$ Young -30 & 10,933 & $0.044 * *$ & 15,655 & $0.053^{* *}$ & 17,674 & $0.045^{* *}$ \\
\hline Pseudo R2 & & & & & & 0.254 \\
\hline $\begin{array}{l}\mathrm{N} \text { of } \\
\text { observations }\end{array}$ & & & & & & \\
\hline
\end{tabular}

Note: Mean corrected. Effect $=$ variation $\partial \mathrm{P} / \partial \mathrm{X}$. Significance level: $* * * \mathrm{p}<0.01, * * \mathrm{p}<0.05, * \mathrm{p}<0.1$. NI stands for "Not Included."

The second results collections are provided by Table 2. In all columns, the regressions include those of the cohort dummies and normalized year dummies. For instance, the dummy variable 
called "Dummy 2001," denotes d3* in equation (8). We think reasonable to construct synthetic birth "cohorts" and perform the regression analysis independently for the urban and rural residents since the geographic mobility of youth workers across urban and rural areas is very high during the period under study as already noted.

Our estimations of the cohort dummies indicate that starting from the cohorts born in 1981, later cohorts are less likely to participate in the labour market than earlier cohorts. The year effects shown in the coefficients of the normalized year dummies are stable regarding the previous estimates presented in Table 1. In fact, the results are similar to those of the previous regressions excluding cohort dummies. Column 5 and 6 of Table 2 presents the full sample estimation results: the year effects for 2001 and 2005 captured by the two restrictions are respectively -0.057 and 0.070 . As the coefficients for the modified year dummies suggest, there is a strong transitory shock that amplified the LFPR of informal workers 2005.

In Table 2, the other regression results for essential explanatory variables (poverty, age, education, marital status, family size, urban dwelling, the percentage of the population engaged in non-agricultural work, and percentage of young -30) are commonly similar to those of the earlier regressions reported in Table 1 . The youth of the population in each area emerges as the single most powerful factor explaining the increase in the LFPR of younger persons in 2001 and 2005, even if the age and cohort effects, as well as the transitory time effect, are performed.

Table 3 takes to account similar regressions separately for each year and the rural and urban areas, excluding the cohort and year dummies. The objective is to see how the effect of each independent variable changed over time. The results suggest a notable difference found across years: the education effect, especially those of college education of the young urban population on the LFP, diminished over time. In particular, the estimated coefficient for a college education is small in 2005. The implication of this result is that many young workers, college graduates in the majority, were obliged to give priority for work by their age in the course of the restructuring of firms after the economic crisis.

Table 3: Results of logistic regressions for each year: variation effect $\partial \mathrm{P} / \partial \mathrm{X}$

\begin{tabular}{|c|c|c|c|c|c|c|}
\hline & \multicolumn{3}{|c|}{ Urban } & \multicolumn{3}{|c|}{ Rural } \\
\hline & 2001 & 2005 & 2010 & 2001 & 2005 & 2010 \\
\hline Poverty & 0.687 & $-0.699 * *$ & 0.686 & $-0.641 * *$ & 0.458 & $-0.683 * *$ \\
\hline Poverty 2 & 0.591 & $-0.583 * *$ & 0.537 & $-0.562 * *$ & 0.363 & $-0.549 * *$ \\
\hline Ages 15-19 & $-0.665 *$ & $-0.590 *$ & $-0.503 *$ & $-0.66 * *$ & -0.552 & -0595 \\
\hline Ages 20-29 & $-0.843 * *$ & $-0.791 * *$ & $-0.742 * *$ & $-0.857 * *$ & $-0.768 * *$ & $-0.787 * *$ \\
\hline Ages 30-39 & $-0.922 * *$ & $-0.907 * *$ & $-0.847 * *$ & $-0.924 * *$ & $-0.862 * *$ & $-0.876 * *$ \\
\hline Elementary school & $0.261^{* *}$ & $0.032 * * *$ & $-0.078 * * *$ & $-0.015 * * *$ & $0.006 * * *$ & $0.192 * *$ \\
\hline Middle school & $0.210 * *$ & $0.058 * * *$ & $-0.091 * * *$ & $-0.340 * *$ & $-0.362 * *$ & $0.038^{* *}$ \\
\hline High school & $0.188 * *$ & $-0.052 * * *$ & $-0.010 * * *$ & $-0.463 * *$ & $-0.475 * *$ & $-0.291 * *$ \\
\hline College & $0.325 * *$ & $0.092 * * *$ & $0.304 * *$ & $-0.416 * *$ & $-0.549 * *$ & $-0.389 * *$ \\
\hline Marital status & $1.063 * *$ & $1.056 * *$ & $0.891 * *$ & $2.258^{* *}$ & $1.996 * *$ & $2.593 * *$ \\
\hline Family size & $0.020 * *$ & $0.008 * * *$ & $0.010 * * *$ & $-0.090 * * *$ & $-0.010 * * *$ & $-0.076 * *$ \\
\hline$\%$ Non-agriculture & $0.014 * *$ & $0.013 * *$ & $0.013^{* *}$ & $0.102^{* *}$ & $0.109 * *$ & $0.032 * *$ \\
\hline$\%$ Young -30 & $0.057 * *$ & $0.016 * *$ & $0.021^{* *}$ & $0.013 * *$ & $0.060 * * *$ & $0.023 * *$ \\
\hline Pseudo R2 & 0.197 & 0.193 & 0.178 & 0.166 & 0.196 & 0.198 \\
\hline
\end{tabular}

Note: Significance level: $* * * p<0.01, * * p<0.05, * p<0.1$.

Interesting results concern the declining in magnitude over time of the effect of the younger generation in the locality on the probability of LFP in both rural and urban areas. Furthermore, the negative estimate of the family size on the probability of being active in the labour market becomes also weaker over time. From 2001 to 2005, its sign even turned positive for the urban sample. In the present case, the influence of these two variables could be the potentially important factors that produced the increase in the LFPR of young persons, cutting down the countervailing 
influences of urbanization attraction or agricultural decline. As the regression results suggest, other things being equal, the LFPR of the young agent is likely to fall over time if the effects of these two variables diminish in the long run. We think that the mass migration of youth to urban areas have produced informal employment. Thus, it is a major explanation for the increase in the LFPR of the urban young persons. The question about why the rise in the share of the younger people in the towns are related to a higher LFPR of younger men and women in the locality is not entirely clear. Perhaps young householders are motivated to start to work informally because they are gaining family labour. The inquiry can also be related to the household size.

Table 4: Results of 2005-2010 pooled-sample logistic regressions: local labour-market conditions and the probability of LFP

\begin{tabular}{|c|c|c|c|c|c|c|}
\hline & \multicolumn{2}{|c|}{ Urban } & \multicolumn{2}{|c|}{ Rural } & \multicolumn{2}{|c|}{ All } \\
\hline & Mean & Effect & Mean & Effect & Mean & Effect \\
\hline Poverty & 0.541 & $-0.610 * *$ & 0.591 & $-0.550 * *$ & 0.491 & $-0.601 * *$ \\
\hline Poverty 2 & 0.495 & $-0.712 * *$ & 0.499 & $-0.467 * *$ & 0.487 & $-0.531 * *$ \\
\hline Ages 15-19 & 0.180 & $-0.629 * *$ & 0.218 & $-0.664 * *$ & 0.202 & $-0.312 * *$ \\
\hline Ages 20-29 & 0.191 & $0.815^{* *}$ & 0.218 & $0.788^{* *}$ & 0.202 & $0.808 * *$ \\
\hline Ages $30-39$ & 0.114 & $0.902 * *$ & 0.146 & $0.905 * *$ & 0.127 & $0.905^{* *}$ \\
\hline Year 2001 & 0.150 & $0.367 * *$ & 0.230 & $0.113^{*}$ & 0.182 & $0.179 * *$ \\
\hline Year 2005 & 0.278 & $0.931 * *$ & 0.146 & 1.049 & 0.226 & $0.548 * *$ \\
\hline Year 2010 & 0.336 & $0.255^{* *}$ & 0.155 & $1.300 * *$ & 0.265 & $0.179 * *$ \\
\hline Elementary School & 0.310 & $0.131 * *$ & 0.482 & $-0.021 * *$ & 0.356 & 0.007 \\
\hline Middle School & 0.189 & $0.291 * *$ & 0.069 & $-0.279 * *$ & 0.153 & 0.027 \\
\hline High School & 0.218 & $0.369 * *$ & 0.037 & $-0.368 * *$ & 0.161 & $0.076 * *$ \\
\hline College & 0.171 & $0.838^{* *}$ & 0.043 & $-0.324 * *$ & 0.118 & $0.439 * *$ \\
\hline Marital status & 0.918 & $0.966 * *$ & 0.912 & $2.563 * *$ & 0.920 & $1.530 * *$ \\
\hline Family size & 3.920 & $-0.032 * *$ & 3.908 & $-0.153 * *$ & 3.876 & $-0.073 * *$ \\
\hline Duration status & 0.212 & $0.457 * *$ & 0.491 & $0.635 * *$ & 0.671 & $0.533 *$ \\
\hline Urban region & 1.000 & NI & 0.000 & $\begin{array}{l}\mathrm{N} \\
\mathrm{I}\end{array}$ & 0.608 & $-0.203 * *$ \\
\hline$\%$ Non-agriculture & 19.414 & $0.014 * *$ & 81.082 & $0.015 * *$ & 43.527 & $0.014 * *$ \\
\hline$\%$ Young -30 & 5.516 & $0.047 * *$ & 10.234 & $0.056 * *$ & 7.361 & $0.051 * *$ \\
\hline$\%$ Participation & 11.415 & $-0.016 * *$ & 7.272 & $0.039 * *$ & 9.793 & $-0.030 * *$ \\
\hline Pseudo R2 & \multicolumn{2}{|c|}{0.221} & \multicolumn{2}{|c|}{0.223} & \multicolumn{2}{|c|}{0.237} \\
\hline $\mathrm{N}$ of observations & \multicolumn{6}{|c|}{27,000} \\
\hline
\end{tabular}

Note: Mean corrected. Effect $=$ variation $\partial P / \partial X$. Significance level: $* * * p<0.01, * * p<0.05, * p<0.1 . N I$ stands for "Not Included."

The more the number of persons in a household, the more the need for material and financial means and so the more people would be motivated to find a job. The households in Cameroon have more than three persons on the average (Amin (2001), even if in parallel, the numbers of one-generation households and single-person households rapidly increased. Since there is a possibility that individual in bigger households might be obliged to have activity in order at least to contribute to the welfare of the family, the household size influence positively the choice to work in the informal sector, as the access to formal jobs is difficult.

To understand why so many younger farmers in Cameroon do not follow the giving on work pattern seen in the past among occidental farmers, further investigation is needed. Agriculture represents more than half of the country non-oil export revenues and employs almost sixty percent of the working population in Cameroon. Moreover, ninety percent of rural households are, in one way or another, employed in agriculture, and approximately one-third of them earn their living from export crops. Therefore, it should be emphasized that the relative deteriorating of the rural economy in the course of modern well-being made it more and more difficult for the young rural people to accumulate revenues. For some authors, the ratio of the income of farm households to 


\section{Tchakounté Njoda Mathurin, MBAM Ulrich Gaetan \\ Labour Force Participation of Cameroonians in Informal Sector}

the income of urban households shows a decreasing trend in the long-term (Bigome and Khadiagala, 1991; Fambon, 2011).

Except for the late 1970s, farm households fared relatively well until the mid-1990s, when the average income of urban households rose rapidly. Insufficient income is not the only way which can force younger persons in rural areas to go off involuntarily in the informal labour force. Circumstantial evidence suggests that a rise in the value of farm properties would stimulate departure of the young rural population. We explore this option by examining the effect of the rate of appreciation of land value between the years 2001 and 2005 in each locality on the probability of LFP of younger men and women who resided in the city. We take the five-year period because it was the only time interval among our Surveys years after 1996 during which the LFPR of younger workers in the countryside areas declined and the average land price grew. We previously found that the sharp decline in the LFPR of rural younger individuals between 2001 and 2005 may have resulted from the deterioration of the labour-market conditions after the economic crisis.

Additional pooled-sample logistic regressions similar to those reported in Table 1 are conducted, to verify if leaving decisions of younger Cameroonian workers was influenced by business cycles. To facilitate regressions, we added, a variable pertaining to labour-market participation of early youth (ages 15 to 29) in each city of residence. Agents who did not work voluntarily are defined as participants, for the purpose of the current analysis. Since it does not provide reasons for not working, the 2005 CNIS middle Survey is not included in the pooled sample. The results are reported in Table 4.

Our simulations considerably support the fact that poor labour-market tightness may have pushed young Cameroonians workers inside of the labour force. As a whole, we can see that the effects of the participation covariate in the models are largely as expected. A change of one-percent increase in the participation rate among prime-age brings about 3 percent incline in the LFPR of the agent. Between 2001 and 2005, the average participation rate of person 20 to 39 in the pooled sample of the Surveys rose from 7.6 percent to 11.3 percent. In this regard, if the regression result is observed, the rigidities of job market should decrease the LFPR of younger men and women by 15 percent. Here we confirm that the flow in informal employment following the economic crisis was the explanation of the exodus of young workers from the labour market after 2001.

\section{CONCLUSIONS}

On both rural and urban areas, the LFP measure is very important for economic activities. This paper has examined LFP of Cameroonians in the informal sector. For this purpose, we have estimated the LFPR of informal workers in Cameroon and analyzed the effects of several determining factors of the LFP decisions at younger ages. The lack of consensus in the literature on how to define and measure informal sector performance constitute one of the major difficulties in being able to identify and understand the informal sector employment.

However, into the Cameroonian working world, the most extraordinary evolution is the increase from 5.088 million in 1995 to 7.410 million in 2010 of the LFP of informal workers ${ }^{11}$. This pattern is sharply similar from the historical experiences of most developing countries that witnessed a considerable incline in the LFP of informal workers over the last century.

As long as the economy does not generate enough jobs in the formal sector, the proliferation of informal activities becomes an indispensable resource for people in working age. At the end of this work, we strongly argued that the explication of the rise in the LFPR of informal workers in Cameroon come to the spectacular increase in the labour-market activity among the urban young people.

To achieve our objective, we use a simple model which determines the main factors of LFP decisions. The model specified in a dichotomous logistic form estimated how the probability of LFP

\footnotetext{
${ }^{11}$ United Nations Statistics Division (May 2010); FAOSTAT (January 2011).
} 


\section{Tchakounté Njoda Mathurin, MBAM Ulrich Gaetan \\ Labour Force Participation of Cameroonians in Informal Sector}

is affected by a quantity of potential variables in LFP decisions, such as poverty, age, cohort, dummies, education, marital status, family size, duration status, and place of residence. For this particular regression analysis, our results maintain that the inflow of prime-age. Generation in urban areas due to the rural exodus of younger persons represents the major cause of the sharp expand in the LFPR of informal workers, ceteris paribus. It is likely that the relative incline of the urban economy during the beginning of last decade in the course of the fight against poverty - the fundamental government goal - made it increasingly difficult for the younger urban men and women to save for leisure or school.

The results of our paper imply that, first the overall LFPR of younger Cameroonians workers is certainly much higher than those in other central African countries; second, the relatively high participation rate may be attributable to the greater proportion of the informalisation among the young; third, the principal determinants of the LFPR of younger workers in Cameroon are poverty, age and urbanisation. Education in itself does not guarantee the creation of higher quality jobs.

\section{REFERENCES}

- Abdulloev, I., Gang, I., Landon-Lane, J. (2012), Migration as a Substitute for Informal Activities: Evidence from Tajikistan, in Lehmann $\mathrm{H}$, Tatsiramos $\mathrm{K}$ (eds), Informal Employment in Emerging and Transition Economies, Research in Labor Economics, vol 34, Emerald Group Publishing Limited, pp. 205-227, CrossRef

- Amin, A. (2001), Rural Poverty and Agricultural Development in Cameroon, Colloque organisé par la Chaire Unesco, Université Montesquieu-Bordeau IV - Unesco Paris du 22 \& 23 novembre 2001, 19 pages.

- Bamou, E. and Masters, W. (2006), Distortions to Agricultural Incentives in Cameroon, Agricultural Distortions Research Project Working Paper, 51 pages.

- Bernabe, S. (2002), Informal Employment in Countries in Transition: A Conceptual Framework, London School of Economics, Centre for Analysis of Social Exclusion, Case Paper, 56, pp. 1-64

- Bigombe, B. and Khadiagala, G. (1991), Major Trends Affecting Families in Sub-Saharan Africa, http://www.un.org/esa/socdev/family/Publications/mtbigombe.pdf

- Blau, D. and Riphahn, R. (1999), Labor Force Transitions of Older Married Couples in Germany, Labour Economics, 6 (2): 229-251, CrossRef

- Blundell, R. and McCurdy, T. (1999), Labour Supply a Review of alternative Approaches, The Institute for Fiscal Studies, Working Paper Series, No. W 98/18.

- CNIS (2005), Enquête sur l'Emploi et le Secteur Informel au Cameroun en 2005, Phase 1 : Enquête sur l'emploi, Main Report.

- CNIS (2011), Deuxième Enquête sur l'Emploi et le Secteur Informel (EESI 2), Phase 2: Enquête sur le Secteur Informel, Rapport Principal, Yaoundé.

- Daza, J. L. (2005), Informal Economy, Undeclared Work and Labour Administration, Dialogue Paper No 9, International Labour Office, Geneva, pp. 1-67.

- Demarsi, D. (1992), Logit Modeling: Practical Applications, Sage Publications, Newbury Park, Calif, CrossRef

- Eapen, M. (2001), Women in Informal Sector in Kerala: Need for Re-examination, Economic and Political Weekly, 36 (26): 2390-2392.

- EDSC-III (2004), Enquête Démographique et de Santé au Cameroun, Note de Présentation des Résultats.

- EDS-MIC (2011), Enquête Démographique et de Santé (EDS) et Enquête par Grappe à Indicateurs Multiples, CNIS, Note de Présentation des Résultats.

- Emini, C., Cockburn, J. and Decaluwe, B. (2005), The Poverty Impacts of the Doha Round in Cameroon: The Role of Tax Policy, World Bank Policy Research, Working Paper N 3746.

- Fambon, S. (2011), Inequality in the Distribution of Household Expenditure in Cameroon, IARIW-Statistics South Africa Conference on Experiences and Challenges in Measuring 
National Income, Wealth, Poverty, and Inequality in African Countries September 28 October 1, 2011, Cape Town, South Africa.

- Funkhouser, E. (1997), Mobility and Labor Market Segmentation: The Urban Labour Market in El Salvador, Economic Development and Cultural Change, 46(1): 123-153, CrossRef

- Gasparini, L. and Tornarolli, L. (2009), Labor Informality in Latin America and the Caribbean: Patterns and Trends from Household Survey Microdata, Desarrollo y Sociedad, 63, 13-80.

- Henley, A., Arabsheibani, G. R., Carneiro, F. G. (2009), On defining and measuring the Informal Sector: Evidence from Brazil, World Development, 37(5), 992-1003, CrossRef

- International Conference of Labour Statisticians ILO (2003), Employment Situation and Trends in China, in Report of the 17th Conference. ILO, Geneva.

- International Labour Office (1972), Employment, Incomes and Equality: A Strategy for increasing Productive Employment in Kenya, Geneva: ILO.

- International Labour Organisation (2002), Women and Men in the Informal Economy, A Statistical Picture, International Labour Organisation: Geneva.

- Jaza Folefack, A. J. (2015), The Rural Exodus of Young Farmers and its Impact on the Shortage of Labor and Food Crop Production in Cameroon: A Computable General Equilibrium Model's Analysis, Journal Human Ecology, 49(3): 197-210.

- Johnson, S., Kaufmann, D., Shleifer, A., Goldman, M. I., and Weitzman, M. L. (1997), The Unofficial Economy in Transition, Brookings Papers on Economic Activity, 1997(2): 159239, CrossRef

- Komon, J.-C. and Tchakounté Njoda, M. (2008), Chômage et Emploi Informel au Cameroun, Revue d'Economie et Gestion Appliquée, 5, pp. 54-79.

- Lacko, M. (2000), Hidden Economy-an Unknown Quantity? Comparative Analysis of hidden Economies in Transition Countries, 1989-95, Economics of Transition, 8(1): 117-149, CrossRef

- Maloney, W. F. (1999), Does Informality imply Segmentation in Urban Labor Markets? Evidence from Sectoral Transitions in Mexico, World Bank Economic Review, 13(2): 275302, CrossRef

- Marcouiller, D., De Castilla, V. R., Woodruff, C. (1997), Formal Measures of the InformalSector Wage Gap in Mexico, El Salvador, and Peru, Economic Development and Cultural Change, 45(2): 367-392, CrossRef

- Mazumdar, D. (1983), Segmented Labor Markets in LDCs, American Economic Review, 73(2): 254-259.

- Merrick, T. W. (1976), Employment and Earnings in the Informal Sector in Brazil: The Case of Belo Horizonte, Journal of Development Areas, 10(3): 337-354.

- Nana, D. J., Ngouana, K. S., Nzeuyang, N. C. et Moukam, C. Y. (2015), Impact des Politiques Fiscales et d'Emploi sur le Secteur Informel au Cameroun, Rapport Final, PEP, 45 pages.

- Ningaye, P. and Talla Fokam, D. N. D. (2014), Labor Market Segmentation and Gender Inequality in Cameroon, International Journal of Business and Economics Research, 3(2): 89-98, CrossRef

- Njikam, G. B. N., Lontchi Tchoffo, R. M. and Mwaffo, V. F. (2005), Caractéristiques et Déterminants de I'Emploi des Jeunes au Cameroun, Employment Strategy Papers, ILO Employment Sector, Employment Strategy Department, Geneva.

- OECD (2008), OECD Employment Outlook, Declaring Work or staying Underground: Informal Employment in seven OECD Countries, Chapter 2, pp. 1-21.

- Pencavel, J. (1986), Labor Supply of Men: A survey, in Ashenfelter, O. and Layard, R. (eds.), Handbook of Labor Economics, vol. 1, pp. 3-102, Amsterdam: Elsevier Science/North-Holland.

- Portes, A., Castells, M., Benton, L. A. (1989), The Informal Economy: Studies in Advanced and Less Developed Countries, Baltimore: John Hopkins University Press, pp. vii-313.

- Pradhan, M. and Van Soest, A. (1995), Formal and Informal Sector Employment in Urban Areas of Bolivia, Labour Economics, 2(3): 275-297, CrossRef 
- SEIS (2010), Deuxième Enquête sur l'Emploi et le Secteur Informel (EESI 2), Phase 1: Enquête sur l'Emploi, Rapport Principal, Yaoundé.

- Takatoshi, I. and Rose, A. K. (2010), The Economic Consequences of Demographic Change in East Asia, University of Chicago Press, 472 pages.

- Tchakounté, N. M. (2008), Flexibilité du Marché de l'Emploi Industriel et Réduction du Chômage au Cameroun, Thèse de Doctorat/ Ph. D, FSEGA, Université de Douala, 282 p.

- Tchakounté, N. M. and Feubi Papem, E. P. (2016), The Effects of Cameroonian Informal Sector on the Scale and Composition of Output, Bulgarian Economic Paper, No. 6, Center for Economic Theories and Policies.

- Tiffen, M. (2003), Transition in Sub-Saharan Africa: Agriculture, Urbanization and Income Growth, World Development, 31(8): 1343-1366, CrossRef

- Tingum, N. E. (2016), Female Labor force participation and Sectoral Choices for females in Cameroonian Labor Market, International Journal of Innovation and Scientific Research, 21(1): 118-129.

- Toossi, M. (2002), A Century of Change: the U.S. Labor Force, 1950-2050, Monthly Labor Review, Bureau of Labor Statistics, pp. 15-28.

- Trani, J. F. (2001), Etre Jeune et survivre à Douala: Activité, Revenu et Position Sociale, Thèse pour le Doctorat d'Economie, Institut d'Etudes Politiques de Paris, 1020 pages.

- UNDP-CMR (2013), Rapport des Consultations Nationales pour l'Agenda post 2015 au Cameroun, 80 pages.

- Zamo-Akono, C. (2013), Disability and Labour Force Participation in Cameroon, International Journal of Human Resource Studies, and 3(2): pp. 1-12.

\section{APPENDIXES}

Table A1: Description of data and variables used in the regression analysis

\begin{tabular}{|c|c|c|c|c|}
\hline No & Variable & Description & Mean & $\begin{array}{l}\text { Standard } \\
\text { deviation }\end{array}$ \\
\hline 1 & Poverty & $\begin{array}{l}1=\text { individual is below the national poverty lines (reference } \\
\text { category); } 0 \text { otherwise }\end{array}$ & 0.500 & 3.040 \\
\hline 2 & Ages $15-19$ & $=1$ for individuals whose age is between 15 and $19 ; 0$ otherwise & 0.746 & 0.129 \\
\hline 3 & Ages 20-29 & $=1$ for individuals whose age is between 20 and $29 ; 0$ otherwise & 0.419 & 0.335 \\
\hline 4 & Ages 30-39 & $=1$ for individuals whose age is between 30 and $39 ; 0$ otherwise & 0.232 & 0.320 \\
\hline 5 & Elementary School & $=1$ if worker education is up to elementary; 0 otherwise & 0.510 & 0.450 \\
\hline 6 & Middle School & $=1$ if worker education is up to middle; 0 otherwise & 0.423 & 0.116 \\
\hline 7 & High School & $=1$ if worker education is up to high; 0 otherwise & 0.115 & 0.413 \\
\hline 8 & College & $=1$ if worker education is up to college; 0 otherwise & 0.052 & 0.345 \\
\hline 9 & Marital status & $=1$ if worker is married; 0 otherwise & 0.222 & 0.138 \\
\hline 10 & Family size & Continuous variable ranging from 1 to 12 persons & 0.179 & 0.383 \\
\hline 11 & Duration status & Continuous variable measure in months & 0.330 & 0.821 \\
\hline 12 & Urban region & $\begin{array}{l}\text { Dummy variable to measure the difference between urban and rural } \\
\text { areas }\end{array}$ & 0.470 & 0.329 \\
\hline 13 & $\%$ Non-agriculture & Continuous variable & 0.671 & 0.704 \\
\hline 14 & $\%$ Young -30 & Continuous variable & 0.140 & 0.347 \\
\hline 15 & $\%$ Participation & Continuous variable & 0.734 & 0.860 \\
\hline 16 & Cohort & $=1$ if yes; 0 otherwise & 0.465 & 0.109 \\
\hline 17 & Dummy & $=1$ if yes; 0 otherwise & 0.692 & 0.535 \\
\hline 18 & $\begin{array}{l}\text { Labour Force } \\
\text { Participation }\end{array}$ & $\begin{array}{l}\text { Dependent variable for the LFP decision }=1 \text { if the individual is } \\
\text { informal employed and reports a wage; } 0 \text { otherwise }\end{array}$ & 0.501 & 0.621 \\
\hline
\end{tabular}


Tchakounté Njoda Mathurin, MBAM Ulrich Gaetan

Labour Force Participation of Cameroonians in Informal Sector

Table A2: Correlations among explanatory variables

\begin{tabular}{|l|l|l|l|l|l|l|l|l|l|l|l|l|l|l|l|}
\hline $\begin{array}{l}\mathrm{N} \\
\mathrm{o}\end{array}$ & 1 & 2 & 3 & 4 & 5 & 6 & 7 & 8 & 9 & 10 & 11 & 12 & 13 & 14 & 15 \\
\hline 1 & 1.000 & & & & & & & & & & & & & & \\
\hline 2 & 0.732 & 1.000 & & & & & & & & & & & & & \\
\hline 3 & 0.581 & 0.398 & 1.000 & & & & & & & & & & & & \\
\hline 4 & 0.311 & 0.645 & 0.097 & 1.000 & & & & & & & & & & & \\
\hline 5 & 0.714 & 0.749 & 0.547 & 0.021 & 1.000 & & & & & & & & & & \\
\hline 6 & 0.399 & 0.646 & 0.690 & 0.081 & 0.018 & 1.000 & & & & & & & & & \\
\hline 7 & 0.229 & 0.444 & 0.711 & 0.123 & 0.067 & 0.047 & 1.000 & & & & & & & & \\
\hline 8 & 0.619 & 0.613 & 0.119 & 0.028 & 0.111 & 0.099 & 0.066 & 1.000 & & & & & & & \\
\hline 9 & -0.436 & 0.044 & 0.709 & 0.584 & -0.095 & 0.136 & 0.138 & 0.148 & 1.000 & & & & & & \\
\hline 10 & 0.376 & 0.602 & 0.200 & -0.167 & 0.216 & 0.108 & 0.336 & 0.764 & 0.615 & 1.000 & & & & & \\
\hline 11 & 0.053 & 0.291 & 0.483 & 0.192 & 0.011 & 0.219 & 0.321 & 0.169 & -0.089 & 0.078 & 1.000 & & & & \\
\hline 12 & -0.194 & 0.565 & 0.326 & -0.323 & 0.251 & 0.296 & 0.816 & 0.118 & 0.032 & 0.151 & 0.322 & 1.000 & & \\
\hline 13 & -0.617 & 0.127 & 0.371 & 0.264 & 0.113 & 0.253 & 0.068 & 0.216 & 0.178 & 0.145 & 0.228 & 0.513 & 1.000 & & \\
\hline 14 & & & 0.057 & 0.050 & 0.790 & 0.312 & & 0.181 & 0.108 & -0.238 & -0.505 & -0.122 & 0.407 & 0.155 & 1.0 \\
\hline 15 & -0.236 & 0.588 & 0.761 & 0.694 & 0.092 & 0.046 & 0.406 & 0.301 & 0.734 & 0.498 & -0.262 & & 0.60 \\
\hline
\end{tabular}

